\title{
'Like a drawing of breath': Leisure-based art-making as a source of respite and identity among older women caring for loved ones with dementia
}

\author{
Authors: Bryony Hunt, Lindsay Truran \& Frances Reynolds
}

This is an Accepted Manuscript (October 2016) of an article published by Taylor \& Francis in Arts \& Health, available online:

http://www.tandfonline.com/doi/full/10.1080/17533015.2016.1247370

Background: Caring for a family member with dementia is stressful. This study explores carers' experiences of leisure-based art-making, and its contribution to psychological well-being.

Method: This study interviewed six women ( $>60$ years old) with lengthy experience of caring for a relative with dementia. All engaged regularly in art-making. Findings were inferred through Interpretative Phenomenological Analysis (IPA).

Results: Participation in art-making promoted positive identity, and resilience for care-giving. It offered temporary respite from care-giving demands, helping participants maintain contact with the richness of the external world, and freedom from confinement. Art-making facilitated meaningful connections with others, including the person with dementia, and enabled positive feedback. Participants whose loved ones had recently died or moved to residential care, processed, in oblique, possibly symbolic ways, the end of their intense involvement in care-giving. Conclusions: The findings suggest that meaningful creative leisure occupations may help to protect the psychological well-being of care-givers, promoting resilience.

Key words: leisure, art, care-givers, dementia, resilience, well-being 


\section{Introduction}

According to Newbronner, Chamberlain, Borthwick, Baxter, and Glendinning (2013), there are about 670,000 people in the UK who provide informal care to a loved one with dementia. Although there are different forms of dementia, such as Alzheimer's and vascular dementia, affected people typically share progressive difficulties with memory, apathy, mood and personality change, and then in the later stages language loss and behavioural disturbances (Srikanth et al, 2005; Steinberg et al 2008). There is substantial evidence that care-givers are vulnerable to high levels of psychological distress, such as depression and anxiety, as well as physical health problems, especially those with fewer resources (Pinquart \& Sörensen, 2007;

Sörensen, Duberstein, Gill, \& Pinquart, 2006). Care-givers of people with dementia are more vulnerable to depression than those providing informal care to loved ones with other long-term illnesses (Schoenmakers, Buntinx, \& Delepeleire, 2010). Many are spouse care-givers who are themselves older and possibly facing poor health (O'Shaughnessy, Lee, \& Lintern, 2010). Not surprisingly, psychological ill-health tends to be worse among those who care for people in the later stages of dementia, for longer hours and with limited support (Sörensen et al., 2006). Camic, Williams and Meeten (2011; p.159) observe that 'although a great deal of attention has been given to the selfhood of the PWD [person with dementia], less focus has been given to that of the carer's sense of self...'. It is recognised that care-givers may experience role engulfment and the sense that care-giving has become a 'master identity' usurping all other sources of personal and social identity (Charmaz, 1994; Eifert, Adams,Dudley, \& Perko, 2015). Some admit to having suicidal thoughts (O'Dwyer, Moyle, \& Van Wyk, 2013). However, care-givers are not a homogenous group and some are more resilient than others, perceiving that life retains some quality, for example through implementing coping strategies, sharing knowledge with friends, feeling able to use support services effectively, maintaining their religious faith, and retaining elements of their former relationship with the loved one affected by dementia (Donnellan, Bennett, \& Soulsby, 2015; O’Dwyer et al., 2013).

There has been some, albeit limited, exploration of whether leisure activities have a role to play in protecting care-givers' psychological well-being, for example, by offering a temporary escape from caring, maintaining a familiar identity and increasing resilience (Gahagan, Loppie, Rehaman, Maclellan, \& Side, 2007; Losada, Pérez-Peñaranda, Rodriguez-Sanchez, Gomez-Marcos, Ballesteros-Rios, Ramos- 
Carrera, \& García-Ortiz, 2010). Lightsey (2006: p.100) portrays resilience as "the belief that one can persevere or accomplish goal-relevant tasks across varied challenges and adverse situations", which has relevance to the taking up or maintenance of creative activities in the midst of the pressures of care-giving. Nonetheless, leisure activities are difficult for care-givers to maintain, with daily routines typically dominated by caring tasks such as accompanying the care receiver to medical appointments, administering medication, and personal care activities including toileting, dressing and bathing (Pickard, Shaw, \& Glendinning, 2000). Caregivers (especially females) are also vulnerable to abandoning valued leisure activities, for lack of autonomy over how to spend their time, difficulties in setting up alternative care arrangements for loved ones, and/or through believing that they are unentitled to leisure or time for self (Gahagan et al., 2007; Schumacher, MacNeill, Mobilily, Teague, \& Butcher, 2012).

In terms of the specific leisure activities that dementia care-givers engage in, and their contribution to coping, a survey by Nolan, Ingram, and Watson (2002) found that care-givers described watching TV, reading, and exercising as reducing their stress. Robinson, Clare, and Evans (2005) conducted a study involving joint interviews with nine married couples, where one member of each couple had dementia. They found that by individually continuing to engage in leisure occupations such as visiting art galleries, painting, and walking, both partners were able to retain aspects of themselves and parts of their lives that were not dominated by dementia.

Older people in general report various physical and mental health benefits from engaging in arts and crafts for leisure (Castora-Binkley, Noelker, Prohaska, \& Satariano, 2010; Fisher \& Specht, 1999; Reynolds, 2010). Such activities are valued for providing cognitive stimulation, self-esteem, social relationships based on mutual interests, distraction from everyday problems, and a sense of purpose. There has been some limited research into the value of carers and their loved ones with dementia attending art galleries or museums together (Camic, Tischler, and Pearman, 2014; McGuigan, Legget and Horsburgh, 2015) or participating in other creative activities together such as singing (Camic, Williams and Meeten, 2011; Hammar, Götell and Engström, 2011). However, the meanings of such activities for caregivers have not been explored in detail. One study has delved into the experiences of care-givers of people with dementia who attended a 5-week creative 
arts intervention (Pienaar \& Reynolds, 2015). This achieved positive outcomes, with participants valuing temporary respite and freedom from caring, and enhanced selfesteem, social support and resilience. Whilst this study showed that a short-term arts intervention was meaningful and stress-relieving for care-givers with little previous art-making experience, there is more to learn about the functions of creative leisure activities that reflect much longer-standing interests and well-developed artistic skills.

The current study sought to explore the meanings of art-making as a committed leisure activity for older women who provide informal care to loved ones with dementia.

\section{Method.}

Methodology:

A qualitative method was appropriate for exploring the subjective meanings of artmaking in depth (Camic, Tischler, \& Pearman, 2014). Interpretative Phenomenological Analysis (IPA) is a qualitative method that seeks to explore participants' lived experiences, paying close attention to their idiographic understandings, whilst accepting that verbal accounts never offer direct access to subjective experience, and that researcher reflexivity is required to limit preunderstandings and selective interpretation as far as possible. Small sample sizes (of 3-6 participants) are recommended in IPA research to facilitate detailed analysis of participants' convergent (shared) and divergent experiences (Smith, Flowers \& Larkin, 2009).

\section{Ethics:}

The project was approved by the university ethics committee. Participants were given detailed information about the project in order to give informed consent. Identities have been masked through use of pseudonyms and withholding any highly identifying personal data.

\section{Recruitment and Participants:}

The study was advertised by contacting national and local organisations concerned with older adults, dementia and voluntary care-givers, and by placing a letter in a national UK magazine aimed at readers who engage in art for leisure. A number of local art classes, day centres and community centres were also contacted. All 
organisations were sent or emailed a letter explaining the study, a poster and an information sheet. People responding to these advertisements were sent full information. In total, nine women were recruited. However, in order to focus on the experiences of older women (and achieve a more homogeneous sample as recommended by Smith et al., 2009), six participants (aged 60-77) provide the sample for this study (See Table 1). Four were caring for husbands with dementia currently or until 4 months previously; two were caring for mothers (in one case until two months previously). Five had engaged in art-making for several years preceding the onset of care-giving responsibilities and one had taken this up whilst care-giving. All had participated in classes and community groups to develop their skills and engaged in this leisure occupation at least weekly.

\section{Interviews:}

Semi-structured, in-depth interviews were selected as they enable rapport to be developed between researcher and participant, and give participants "the space to think, speak and be heard" (Smith et al., 2009; p57). The topic guide for the interviews was shared with participants to enable informed consent (Table 2). Five interviews were conducted in the participants' homes, and one was conducted by telephone, at the participant's request. All were audio-recorded and transcribed verbatim. The length of the interviews was approximately 90 minutes, with the telephone interview of similar length and richness.

To explore the meanings of their art-making in more depth, participants who were interviewed face-to-face brought some examples (objects or photographs) to the interview and/or showed the interviewers some of the artwork on display in the home. The telephone interviewee emailed some photographs of her artwork prior to the interview. Please see Table 2, question 7 for the areas of discussion that were followed in relation to items of artwork. Photo-elicitation interviews are reported to be an effective means of developing rapport and facilitating reflections which may otherwise remain unheard (Clark-Ibáñez, 2004). In the context of art-making, it was anticipated that the sometimes intense physical and emotional processes of creativity might be communicated more vividly when participants focused on specific examples of artwork rather than solely describing the creative process in more abstract terms. Interview reflections were enriched by changing focus from general description to a more specific analysis of the making of selected pieces. This change 
of focus also helped the interviewers to manage potential distress. For example, when one participant (Pamela) became tearful recounting how she no longer had the time to think deeply about her artwork, the interviewer was able to gently ask her to describe how she created an item of which she was particularly proud. The ensuing break in the interview to fetch the item and recover composure seemed to be welcomed by the participant.

The first two authors attended all home interviews to reduce any potential lone working risks. The roles of leading the interview and taking field notes were alternated between these researchers. The telephone interview was conducted by the first author, and recorded using speaker-phone technology. No care recipient was present during the interviews.

Whilst the interview was expected to focus primarily on the positive experiences of art-making (a self-chosen leisure pursuit), the possibility of substantial distress in relation to caring was anticipated. If this had occurred, local care-givers' support agencies would have been recommended, but this was not needed. The interviews were all ended by reviewing positive points made during the interview or by emphasising the quality of the artwork shown during the interview, to minimise any distress.

\section{Data analysis:}

The interview data were analysed following the principles of IPA (Smith et al., 2009), initially inferring themes related to care-giving and then exploring the meanings of art-making in this context (Tables 3 \& 4). Stages included reading and re-reading the interview transcripts, noting emerging meanings in one margin in an exploratory way, and then working on identifying and refining the higher order themes in the other margin. The researchers shared the analysis, discussing and thereby resolving any differences of interpretation to enhance credibility. Sensitivity to meaning was further increased by paying close attention to participants' metaphors or other turns of phrase. Analysis proceeded idiographically, initially seeking an in-depth understanding of each participant's account, and then moving to identifying shared themes and subthemes. Attention was also paid to divergent views. 


\section{Findings:}

In common with other informal care-givers, participants described their experiences of looking after their loved with dementia as relentless, often exhausting, and eroding their identities (as summarised in Table 3). Regardless of their loved one's specific diagnosis, they described how their care-giving responsibilities had increased insidiously, and their ever-present worry ('you're concerned about their health, you're concerned about your own future, how it's affecting you'). Participants grieved for the loved one they had lost to dementia, lamenting role reversal, and the loss of control over many aspects of daily life. Constant supervision was exhausting:

'Once he is home I really have to watch him all the time...because I have to be aware of where he is because he will... start eating paper or something' (Gail).

However, as a group, they portrayed resilience and shared a resolve to make the best of their difficult circumstances:

'Do the best you can and... do the things that you want to do when you can, that's as good as it gets really' (Pamela)

It is possible that this resolve assisted them in maintaining at least weekly involvement in their arts and crafts:

'Through the adversity of all the trauma, I was still able to achieve something for my own personal satisfaction' (Joy)

Art-making was highly valued for providing episodes of respite from caring; for affirming an identity independent of care-giving and increasing resilience (the capacity to achieve something positive amidst the ongoing stress of their daily lives); and maintaining positive connections with others (including the care recipient). Each of the three themes was present in every participant's narrative although there were clear nuances in their art-making experience, and not everyone shared every subtheme. Each participant alluded to art-making as a document of their care-giving journey. For three of the participants whose intense care-giving had recently ended (due to their loved one's death or transfer to a care home), art-making also offered a means of processing this transition. These participants also felt that their art had undergone significant changes since their care-giving role had ended. These three key themes and a number of subthemes are presented in Table 4. 


\section{'Like a drawing of breath': Art-making provides a profound sense of respite from caring and confinement}

Participants described their care-giving responsibilities as often confining and exhausting. They understood some of their artwork (albeit sometimes in retrospect), as expressing (often obliquely) their sense of feeling overwhelmed or submerged by this role, or conveying the relentless attention to detail that was part of their everyday lives as responsible care-givers:

'If I'm drawing a branch or a tree that's got seventeen branches on it, I draw seventeen branches... I've been weighed down for such a long time and I think that's probably part of the reason why everything has to be in such fine detail' (Catherine).

Showing artwork during the interview enabled participants to reflect on the ways that they had expressed overwhelming care-giving experiences in vivid yet oblique ways. Joy showed a seascape painting and commented:

'That [showing the picture to the interviewer] is when I was in such a turmoil, and that wave is boom, it is coming back over you, and it was engulfing' (Joy).

Participants felt that their art-making offered respite ('a total escape') through deep immersion in colour, texture and imagery, enabling them to set aside their caregiving concerns for short periods, and 'play' without adverse consequences, literally 'without caring'.

I'm enjoying ... the feeling of putting on thick paint, perhaps with a palette knife or something, and just getting messy and just, generally just not caring' (June).

Such vivid descriptions of the artistic process and its enjoyable, interactive and immersive qualities were particularly communicated in dialogue with selected examples of artwork in the interviews:

'That's work in process at the moment [points to a large unfinished canvas of poppies in a field], water colour paper, completely wash it in water, and then you just drop the inks in, choose your colours ... but leaving some white spaces ... Ohh the effect was absolutely phenomenal, and of course, like the yellows and the blues just ran in, so you got greens, and it was like these great spikes, like anenomes, all coming out ... it was quite exciting, you know, 
you think 'ahh what's happening there', you know, but that's a real splishy, sploshy thing ...very loosening, yeah" (Joy)

Art-making offered a valued opportunity to relax and gain a revitalising space away from care-giving.

'Kept me sane.... it gives you a break from the responsibility and tedium of it all... just kind of like a drawing of breath I suppose...if that's all you've got in your life, the care-giving, then you're gonna crack... And I would crack, I know. If that was all there was in life' (Catherine).

For all participants, art-making offered refreshing opportunities to explore and experiment. Unlike the relentlessness of care-giving, where lack of attention could result in the care recipient having a serious accident, unexpected outcomes whilst experimenting with paint or other media could be pleasing and/or instructive:

'You have a positive outcome whatever- doesn't matter whether you're happy with what you've done or whether you could've done better; you've learnt something from doing it' (June).

Participants described some of their artwork as expressing both the confinement of care-giving and hope:

'This one [shows a landscape painting]...was quite dark and thundery but there was, the sun was just coming through and catching a tree... I think it's just capturing that bit of light at the end of a rather dark tunnel' (June).

Within this everyday sense of confinement, art-making offered a psychological means of escape and freedom. For example, Joy described painting abstract forms as 'freedom, movement, sort of loosening up, relaxing'. 'Loosening up' was also a shared artistic response to the transition out of care-giving for those whose loved ones had recently died or moved into residential care.

'That was an experimental thing... I wanted movement so I got that swirly movement, and then I wanted something a bit splashy... away from my usual, tight detailed drawing... A bit splishy, splashy, abstracty... freedom, freedom, movement, yes, sort of, loosening up, relaxing... Getting my life back... shedding all those really heavy, heavy years' (Joy). 
The three participants whose intense involvement in care-giving had recently ended, all perceived their artwork to have subsequently undergone a transformation of style or subject matter. For example, Catherine described returning to her painting class following the death of her mother, and challenging herself to complete a painting that was 'completely out of character', adopting a more impressionist style. She was proud of her achievement that day:

'To start that [shows picture to the interviewer], finish it in one day, was just 'yesss. ' And it means I'm loosening up a little bit ... that's why I want to do the impressionist style because it is looser, the whole thing about it is looser' (Catherine).

The three participants whose care-giving had recently ended all felt they had used their art-making as a means of obliquely processing this important transition in their lives, and to look ahead:

I got it properly framed, and it's been up there, and that's an absolute favourite now... It slightly reminds me of turmoil, but at the same time it says to me 'yes, you got through it.' And what have I started painting now? Peaceful sun sets [laughs]' (Joy).

\section{'It's part of me': Self-expression through art-making enhances self-identity and resilience}

All of the participants reported ways in which care-giving had threatened their sense of identity. They described being seen as 'the enemy' (June) or a 'total stranger' (Joy) by their care recipient. Joy commented that other people tended to know her only in her care-giving role:

'You become a bit grey, you disappear, and you almost get labelled "Oh yes, that's Joy over there, she cares for husband."....Your identity goes when you... have been a long term care-giver" (Joy).

The participants all viewed care-giving as an unavoidable obligation which led to a complex mix of feelings of love and commitment but also frustration, resentment and powerlessness. Art-making provided an antidote to obligation through offering control 
and autonomy, and time for self, thereby protecting a familiar identity, that was not totally defined by their care relationship.

'Well, it is something above and beyond the ordinary everyday chores... it's something that I enjoy just for me because I like doing it, not because I have to do it' (Helen)

Unlike care-giving, this self-directed creative activity had no negative repercussions and invited no judgement from anyone else.

'I don't like to paint if I feel I've got to... Yes, [art offers] an autonomy over what I do.... I think that's really quite important. I don't think I'd bother at all if I thought I was having to do it to please somebody else' (June).

Participants' arts and crafts reaffirmed their individuality, self-esteem, purpose and place within the world. Gail took pleasure in being the only person in her art group 'who made vessels...no one else did that... I originated that'. For nearly all of the participants, apart from Helen for whom painting was a relatively new interest, artmaking and having a general interest in the arts had always been part of their adult life, and therefore was something they strongly identified with:

'I do like arty things, it's part of me, I always have liked that sort of thing' (Pamela).

'I've had a good day when something exists at the end of it that didn't exist at the beginning... I feel it's a day that's not been wasted. And I think, I think that's probably a need in me' (Catherine).

The participants described many ways in which art-making was helping them to maintain or restore their positive sense of identity, and better manage the demands of care-giving.

'I guess if you make something and you feel it's OK then that's quite good for your self-esteem, it makes you feel a bit better about yourself, because some days you feel not too good' (Pamela).

'It just put me back into being my normal person instead of this rather... angry, stressed shell' (June).

However, a divergent view was noted in that Pamela expressed a struggle to maintain sufficient attention to her artwork amidst the sheer intensity of caring. 
Although she certainly derived some satisfaction from her creative activities, she also admitted some frustration:

'The thing about being a carer and living the life that I lead now, it actually stifles all my real creativity, absolutely stifles it, I can't think about being really creative... because my head is constantly full of practical things... it's full of the frustration of the whole set up... where[as] I used to... my head would be buzzing with ideas' (Pamela).

On the other hand, some felt it imperative to set aside time each day for art-making to maintain their own well-being and sense of continuity amidst a deteriorating situation.

'I would have to make something... every day I felt I needed to do something creative' (Gail)

Unlike many other coping strategies, art-making provided a tangible representation of coping and resilience. This was particularly appreciated in retrospect by those whose intense care-giving role had recently ceased, as they drew meaning from reviewing their artwork, and its changing style and imagery during the last few months:

"It slightly reminds me of the turmoil but at the same time it says to me 'yes, you got through it... Because they [a series of paintings] actually were part of the process of me becoming well again '(Joy).

New interpretations were sometimes formulated during the interview itself when discussing specific pieces of artwork:

Interviewer: 'What do you feel when you look at it [a seascape painting] now?' Joy: 'Peace, sunny, sunny day, lovely summery, lovely summery, hot day ... there's no wake on the boat, so the boat is travelling slowly, peaceful, yeah it's not turbulent, not like the wave is turbulence, yeah I, I must admit I didn't, I never, like I said earlier, I never realised that there is a feeling as to how you are at the time'

Several participants believed that their creative activities increased their resilience thereby enabling them to continue with their care-giving responsibilities: 
'It's something other than the routine things of every day that you do [when doing artwork], you see different people... it sort of bucks you up a bit. If you sit at home every day, you ... end up in a semi-stupor' (Helen).

This sense of re-invigoration was also confirmed by Joy, who described feeling refreshed and energised after a two-day art course:

'I came home completely revitalised' (Joy).

\section{'Keeping that link going': Art-making facilitates meaningful connections with a world outside of care-giving}

Art-making offered participants healthy connections with the world beyond caregiving. Most of the participants drew inspiration for their art-making from nature and were highly attuned to colour, texture and form:

I loved all the warm stone in that [picture], the colours of the stone, and trying to achieve the look of glass, in fact there is a lot of textures... glass, stone, foliage, and wood... a lot of different textures to achieve' (Joy)

Art-making also helped maintain meaningful relationships with others, including (for some) the care recipient. For example, Helen described painting with her husband. Within this activity, they could interact in ways that were reminiscent of their predementia relationship, by-passing his cognitive difficulties:

'We are doing it together and we are both interested in the same thing and I can give him suggestions and he can give me suggestions, and it's the togetherness of it, I suppose' (Helen)

Certain pieces of artwork made in previous years reminded some participants of happier times, and a life beyond dementia and care-giving. For Joy, her paintings and cross stitch offered a visual diary, of carefree days that she had enjoyed with her husband before the onset of his dementia. This helped her not only to remember him in better times but to sustain her relationship with him during his illness: 
'That [cross-stitch picture] really was at the time when David first went into retirement and we had that lovely little period of not too many responsibilities... now that's bringing back memories of that time' (Joy)

Participants appreciated when others responded positively and saw them as individuals with their own interests and skills, in addition to being a care-giver:

"I think when you do something creative, it's suddenly "Oh, that's Joy's work yes... that's Joy the artist'" (Joy).

All had participated in art classes or art groups and valued the relationships they had developed there, which offered camaraderie, mutual support and opportunity to interact with like-minded people in a world outside of caring:

'We [in the art class] really have gone our own way in a lot of ways, but we do gain a lot from each other, and it's just companionship and support and just keeping that link going' (Pamela).

'It was special because I was mixing amongst different age groups...I was with like-minded people, and it gave me back my own individuality' (Joy).

Art-making provided a focus beyond care-giving, including plans for interesting future projects, alleviating low mood and sense of entrapment. For those whose loved ones had recently died or moved into residential care, art-making helped with the transition out of care-giving, by providing a wide range of future projects:

'And there's so much to move on to, isn't there? You know, there are so many different styles of painting. I want to do the watercolours... I want to do pastels. I want to do great big paintings and I want to do the tiny little detailed paintings. I want to do pen and ink ones with the wash on the background. There's just so much in life to do, there really is' (Catherine).

\section{Discussion}

The participants' experiences of caring for their family member with dementia very much resonated with previous qualitative research. Psychological well-being was challenged by lack of free time, sense of confinement, loss of autonomy, feelings of helplessness and erosion of identity, as found previously among carers (Hasselkus \& 
Murray, 2007, O'Shaughnessy et al, 2010; Vikström, Josephsson, Stigsdotter-Neely, Nygard, 2008). Their accounts confirmed Wiles (2003; p1322) who concluded that "care-giving comes to dominate every experience; corporeal, emotional, social and spatial". Despite these restrictions, five of the six participants had maintained their long-standing engagement in art-making as a leisure activity throughout their time as care-givers and one had taken up regular art classes since her loved one developed dementia.

For these older women, art-making as a leisure occupation re-affirmed their sense of personal and social identity, fulfilled an intrinsic need to create, afforded a sense of autonomy, and provided a focus and freedom beyond the realms of care-giving. Their art-making thereby helped them resist the 'master identity' all-too-often associated with care-giving, which swamps other sources of selfhood (Charmaz, 1994; Eifert et al, 2015). It fostered a positive emotional and social connection not only with the care recipient but with the world beyond care-giving. Participants found a deep sense of respite which enabled them to return to care-giving, feeling less depleted.

The themes broadly resonated with those inferred in an intervention study of carers taking part in a brief 5-week arts leisure programme, incorporated as part of their ongoing weekly support meetings (Pienaar \& Reynolds, 2015). The participants in the previous intervention study were either new to art- and craft-making or had not engaged in such activities for many years. Carers in this current study had engaged in their creative leisure occupations for much more extended periods, both at home and in classes. Perhaps their comfort with art-making and well-developed skills enabled some to express their negative feelings in symbolic or oblique ways, a welcome contrast to sustaining a positive façade with the care recipient and others. They reported gaining insight and understanding about their care-giving experience from 'seeing' its expression in their art works, which made their feelings more tangible. This benefit is recognised by art psychotherapists (Dekker, 1996; Malchiodi \& Rozum, 2012) but might not be anticipated as an outcome of leisure-based artmaking.

Previous studies have found that leisure-based art-making maintains and transforms identity both for those living with physical health and mental health problems, 
although the experiences of care-givers have been largely neglected. Creative activities can help to bridge the gap between former and current identities and create a sense of normalcy, in times of transition and identity crisis (Van Lith, Fenner, \& Schofield, 2011). Art-making also provided feelings of escape from confinement, associated with close attention to the aesthetic qualities of the environment, deep immersion or flow during the creative process, eliciting of positive memories, and encouraging plans for the future. These benefits were richly illustrated in grounded discussions of particular items of artwork within the interview. Previous research has noted the inherently absorbing flow-like qualities of art-making (Reynolds \&Prior, 2006), with some people likening the experience to 'going on holiday' (Van Lith et al, 2011, pg.656), further illuminating its restorative aspects. The value placed on the restorative and respite aspects of art-making was understandable, given that dementia care-givers report craving chances for solitude and 'restoration of the mind' (Vikström et al, 2008, pg.259).

Through mutual interests in art-making, participants were able to relate to others in fresh ways that were unrelated to caring, which in turn appeared to reinforce their own sense of identity. This finding concurs with evidence about the social value of creative activities for older people who face isolation (Greaves \& Farbus, 2006; Reynolds, 2010). Furthermore, art-making enabled some of the carers to feel closer to the care recipient. Sharing their creative pursuit appeared to restore a valued sense of reciprocity in the relationship, a need reported by other dementia carers as they attempt to fill the gaps that the dementia leaves behind (Gillies \& Johnston, 2004; Searson, Hendry, Ramachandran, Burns, \& Purandare, 2008), and reclaim the sense of 'togetherness' they experienced with their family member prior to dementia (Vikström et al., 2008). Using mutual interests in art to protect the care-recipient's identity and promote togetherness has also been observed by Camic et al. (2014), and needs further research into its meanings for both care-givers and carerecipients.

Taken together, these positive experiences appeared to promote resilience among this group of older women, contributing to their ability not only to cope with the demands of care-giving but to achieve a measure of flourishing within that stressful context. Clearly, resilience is derived from many personal and contextual factors, and art-making activities are only likely to offer one avenue of support. Nonetheless, 
this leisure activity seemed to encourage a sense of continuity, positive identity and social support, all of which underpin resilience among dementia care-givers (Donnellan et al., 2015).

\section{Critical evaluation:}

Positively, the small sample aided in-depth analysis and quotation, as advocated by Smith et al. (2009). Analysis was strengthened by peer review. However, participants were all white, British women living in and around London, largely from relatively socially advantaged backgrounds. Whilst this increased the sample's homogeneity (as advocated by Smith et al., 2009), the sample cannot be considered representative of all carers, and the findings cannot be straightforwardly generalised. Participants reported engaging in art-making before, during and (in some cases) after their care-giving role had ended, so the findings cannot be extended to caregivers new to art-making. Participants were recruited through established arts and caring groups and the researcher acknowledges therefore that the findings may have been different if more socially isolated carers had taken part. They appeared to be in good health, so may be regarded as an advantaged group of older people. It is also acknowledged that not all carers have the time to engage in meaningful leisure activities such as arts and crafts, even on a weekly basis, or be in a position to give time to a research interview.

Whilst the participants' and researchers' shared interest in arts and crafts served as a common link which aided credibility and rapport, it may also have affected how much participants felt they needed to elaborate, on the assumption that the interviewer was already familiar with creative experiences. However, the interviewers emphasised that they were interested in learning from each participant's personal experience, and encouraged elaboration.

The direct examination and discussion of selected items of artwork within the interviews (akin to the photo-elicitation technique) was fruitful in providing vivid examples of the creative process and exploring its potential meanings, of changing the rhythm of the interview to promote episodes of deeper reflection, and providing opportunities to affirm the participant's skills and achievements. It might be illuminating, in future research, to ask participants to provide some examples that were made at different points in the care-giving trajectory, for further insight into how 
artistic imagery and style might evolve in relation to coping with the demands of this role. Nonetheless, it is accepted that personal interpretation of the oblique meanings contained within any piece of art is likely to change over time, rather than ever being finalised and definitive.

The care recipients were not consulted about whether their loved one's creative activities influenced their own well-being in any way, and this might form the focus of future studies. The person with dementia might, for example, perceive that their care-giver's art-making offers an alternative means of communication (Zeilig, 2016 ), provides mutual interests that enhance relationship, or alleviates stress.

Although the study's findings indicate that committed engagement in art-making may offer various experiences that provide temporary, but meaningful psychological respite from care-giving, thereby enhancing psychological well-being, it is acknowledged that other antecedent factors, such as having an optimistic personality or strong social support networks, could be important. Further research is needed to explore how creative art-making intersects with these other facets of resilience.

\section{Conclusion}

This study explored the meanings of leisure-based art-making for older women caring for loved ones with dementia. The participants found that their art helped them resist the 'master identity' associated with care-giving, and they described gaining a more positive sense of self, enjoying temporary but meaningful respite, which enhanced their psychological well-being. Art-making offered deep absorption or flow, temporary relief from worry, and meaningful connection with a world beyond caregiving. For some, making art with the person with dementia (or viewing the artwork together) helped them to feel closer and recovered aspects of their pre-dementia relationship. Regular participation in arts and crafts occupations, even for short periods of time each week, appeared to compensate for some of the voids the women reported experiencing as a result of the 'engulfing' nature of their caring role. It is recommended that community services not only provide practical assistance, but also help care-givers enrich their own lives through identifying leisure occupations that may enhance coping and resilience. The oblique, possibly symbolic expression of painful feelings through nonverbal art-making may also be restorative for some care-givers, and this is also a topic worthy of further study. 
Acknowledgements: The authors are grateful to the participants who shared their stories. The research was self-funded. There are no conflicts of interest.

\section{References}

Camic, P. M., Tischler, V., \& Pearman, C. H. (2014). Viewing and making art together: A multi-session art-gallery-based intervention for people with dementia and their carers. Aging \& Mental Health, 18, 161-168. doi:10.1080/13607863.2013.818101

Camic, P. M., Williams, C. M. \& Meeten, F. (2011). Does a 'singing together group' improve the quality of life of people with a dementia and their carers? A pilot evaluation study. Dementia, 12, 152-171. doi: 10.1177/1471301211422761

Castora-Binkley, M., Noelker, L., Prohaska, T., \& Satariano, W. (2010). Impact of arts participation on health outcomes for older adults. Journal of Aging, Humanities, and the Arts, 4, 352-367. doi:10.1080/19325614.2010.533396

Clark-Ibáñez, M. (2004). Framing the social world with photo-elicitation interviews. American Behavioral Scientist, 47, 1507-1527. doi:10.1177/0002764204266236

Charmaz, K. (1994). Identity dilemmas of chronically ill men. The Sociological Quarterly, 35(2), 269-288. doi: 10.1111/j.1533-8525.1994.tb00410.x

Dekker, M. (1996). Why oblique and why Jung? In J. Pearson (Ed.), Discovering the self through drama and movement (pp39-45). London: Jessica Kingsley.

Donnellan, W. J., Bennett, K. M., \& Soulsby, L. K. (2015). What are the factors that facilitate or hinder resilience in older spousal dementia carers? A qualitative study. Aging \& Mental Health, 19, 932-939.

doi:10.1080/13607863.2014.977771

Eifert, E. K., Adams, R., Dudley, W., \& Perko, M. (2015). Family caregiver identity: A literature review. American Journal of Health Education, 46(6), 357-367. doi: 10.1080/19325037.2015.1099482

Fisher, B.J. \& Specht, D.K. (1999). Successful aging and creativity in later life. Journal of Aging Studies, 12, 457-472. doi:10.1016/S0890-4065(99)00021-3 Gahagan, J., Loppie, C., Rehaman, L., Maclellan, M. \& Side, K. (2007). "Far as I get is the clothesline": The impact of leisure on women's health and unpaid 
caregiving experiences in Novia Scotia, Canada. Health Care for Women International, 28, 47-68. doi:10.1080/07399330601003408

Gillies, B., \& Johnston, G. (2004). Identity loss and maintenance: commonality of experience in cancer and dementia. European Journal of Cancer Care, 13, 436-442. doi: 10.1111/j.1365-2354.2004.00550.x

Greaves, C.J. \& Farbus, L. (2006). Effects of creative and social activity on the health and well-being of socially isolated older people: outcomes from a multimethod observational study. The Journal of the Royal Society for the Promotion of Health, 126, 134-142. doi: 10.1177/1466424006064303

Hammar, L. M., Götell, E., \& Engström, G. (2011). Singing while caring for persons with dementia. Arts \& Health, 3, 39-50. doi:10.1080/17533015.2010.481289

Hasselkus, B. R., \& Murray, B. J. (2007). Everyday occupation, well-being, and identity: The experience of caregivers in families with dementia. American Journal of Occupational Therapy, 61, 9-20. doi:10.5014/ajot.61.1.9

Lightsey, O. R. (2006). Resilience, meaning, and well-being. The Counseling Psychologist, 34(1), 96-107. doi: 10.1177/0011000005282369

Losada, A., Pérez-Peñaranda, A., Rodriguez-Sanchez, E., Gomez-Marcos, M.A., Ballesteros-Rios, C., Ramos-Carrera, I.R., \& García-Ortiz, L. (2010). Leisure and distress in caregivers for elderly patients. Archives of Gerontology and Geriatrics, 50, 347-350. doi:10.1016/j.archger.2009.06.001

Malchiodi, C. A., \& Rozum, A. L. (2012). Cognitive-behavioral and mind-body approaches. In Malchiodi, C. (Ed.) Handbook of Art Therapy (pp. 89-103). New York: Guilford Press.

McGuigan, K. A., Legget, J. A., \& Horsburgh, M. (2015). Visiting the museum together: Evaluating a programme at Auckland Museum for people living with dementia and their carers. Arts \& Health, 7, 261-270.

DOI:10.1080/17533015.2015.1045531

Newbronner, L., Chamberlain, R, Borthwick, R, Baxter, M., \& Glendinning, C. (2013). A road less rocky: Supporting carers of people with dementia. Research Report. London: Carers Trust. Retrieved from http://php.york.ac.uk/inst/spru/pubs/2639/

Nolan, M., Ingram, P. \& Watson, R. (2002). Working with family carers of people with dementia: 'Negotiated' coping as an essential outcome. Dementia, 1, 75-93. doi: $10.1177 / 147130120200100104$ 
O'Shaughnessy, M., Lee, K., \& Lintern, T. (2010). Changes in the couple relationship in dementia care: Spouse carers' experiences. Dementia. doi:10.1177/1471301209354021.

O'Dwyer, S., Moyle, W., \& Van Wyk, S. (2013). Suicidal ideation and resilience in family carers of people with dementia: A pilot qualitative study. Aging \& Mental Health, 17, 753-760. doi:10.1080/13607863.2013.789001

Pickard, S., Shaw, S., \& Glendinning, C. (2000). Health care professionals' support for older carers. Ageing and Society, 20, 725-744. Retrieved from http://journals.cambridge.org/action/displayAbstract?fromPage=online\&aid=68 945\&fulltextType=RA\&fileld=S0144686X01007991

Pienaar, L., \& Reynolds, F. (2015). 'A respite thing': A qualitative study of a creative arts leisure programme for family caregivers of people with dementia. Health Psychology Open, 2, 2055102915581563. doi: 10.1177/2055102915581563

Pinquart, M .\& Sörensen, S. (2007). Correlates of physical health of informal caregivers: a meta-analysis. The Journals of Gerontology Series B: Psychological Sciences and Social Sciences, 62, P126-P137. Retrieved from http://psychsocgerontology.oxfordjournals.org/content/62/2/P126.full

Reynolds, F. (2010). 'Colour and communion': Exploring the influences of visual artmaking as a leisure activity on older women's subjective well-being. Journal of Aging Studies, 24, 135-143. doi:10.1016/j.jaging.2008.10.004

Reynolds, F., \& Prior, S. (2006). Creative adventures and flow in art-making: A qualitative study of women living with cancer. The British Journal of Occupational Therapy, 69(6), 255-262. doi:10.1177/030802260606900603

Robinson, L., Clare, L. \& Evans, K. (2005). Making sense of dementia and adjusting to loss: Psychological reactions to a diagnosis of dementia in couples. Aging \& Mental Health, 9, 337-347. doi:10.1080/13607860500114555

Schoenmakers, B., Buntinx, F., \& Delepeleire, J. (2010). Factors determining the impact of care-giving on caregivers of elderly patients with dementia: A systematic literature review. Maturitas, 66, 191-200. doi:10.1016/j.maturitas.2010.02.009

Schumacher, L.A.P., MacNeill, R., Mobilily, K., Teague, M. \& Butcher, H. (2012). The leisure journeys for sandwich generation caregivers. Therapist Recreation Journal, 46, 42-59. Retrieved from http://js.sagamorepub.com/tri/article/view/2548 
Searson, R., Hendry, A. M., Ramachandran, R., Burns, A., \& Purandare, N. (2008). Activities enjoyed by patients with dementia together with their spouses and psychological morbidity in carers. Aging and Mental Health, 12, 276-282. doi:10.1080/13607860801956977

Smith, J. A., Flowers, P., \& Larkin, M. (2009). Interpretative phenomenological analysis: Theory, method and research. London: Sage Publications.

Sörensen, S., Duberstein, P., Gill, D., \& Pinquart, M. (2006). Dementia care: mental health effects, intervention strategies, and clinical implications. The Lancet Neurology, 5, 961-973. doi:10.1016/S1474-4422(06)70599-3

Srikanth, S., Nagaraja, A. V., \& Ratnavalli, E. (2005). Neuropsychiatric symptoms in dementia - frequency, relationship to dementia severity and comparison in Alzheimer's disease, vascular dementia and frontotemporal dementia. Journal of the Neurological Sciences, 236(1), 43-48. doi.org/10.1016/j.jns.2005.04.014

Steinberg, M., Shao, H., Zandi, P., Lyketsos, C. G., Welsh-Bohmer, K. A., Norton, M. C., ... \& Cache County Investigators. (2008). Point and 5-year period prevalence of neuropsychiatric symptoms in dementia: the Cache County Study. International Journal of Geriatric Psychiatry, 23(2), 170-177. doi: 10.1002/gps. 1858

Van Lith, T., Fenner, P. \& Schofield, M. (2011). The lived experience of art making as a companion to the mental health recovery process. Disability and Rehabilitation, 33, 652-660. doi:10.3109/09638288.2010.505998

Vikström, S. Josephsson, S. Stigsdotter-Neely, A. Nygard, L. (2008). Engagement in activities: Experiences of persons with dementia and their caregiving spouses. Dementia, 7, 251-270. doi: 10.1177/1471301208091164

Wiles, J. (2003). Daily geographies of caregivers: mobility, routine, scale. Social Science\& Medicine, 57, 1307-1325. doi:10.1016/S0277-9536(02)00508-7 Zeilig, H. (2016). Mark making: methodologies and methods. Dementia, 15, 12951305. doi: $10.1177 / 1471301215595926$ 
Table 1: Participants' details

\begin{tabular}{|c|c|c|c|c|c|c|}
\hline & Pseudonym & $\begin{array}{l}\text { Approx } \\
\text { age }\end{array}$ & $\begin{array}{l}\text { Care } \\
\text { experience }\end{array}$ & $\begin{array}{l}\text { Care } \\
\text { recipient }\end{array}$ & Arts/ crafts & $\begin{array}{l}\text { Location } \\
\text { of } \\
\text { interview }\end{array}$ \\
\hline 1. & June & 65 & $\begin{array}{l}\text { Former (until } \\
\text { about } 3 \\
\text { months } \\
\text { previously) }\end{array}$ & $\begin{array}{l}\text { Mother } \\
\text { (with } \\
\text { Alzheimer's) }\end{array}$ & Painting & Home \\
\hline 2. & Gail & 77 & Current & $\begin{array}{l}\text { Husband } \\
\text { (with } \\
\text { vascular } \\
\text { dementia } \\
\text { and possible } \\
\text { Alzheimer's) }\end{array}$ & $\begin{array}{l}\text { Collage, } \\
\text { painting }\end{array}$ & Home \\
\hline 3. & Helen & $60 \mathrm{~s}$ & Current & $\begin{array}{l}\text { Husband } \\
\text { (with non- } \\
\text { specified } \\
\text { dementia) }\end{array}$ & $\begin{array}{l}\text { Painting, cross } \\
\text { stitch }\end{array}$ & Phone \\
\hline 4. & Catherine & 60 & $\begin{array}{l}\text { Former (until } \\
2 \text { months } \\
\text { previously) }\end{array}$ & $\begin{array}{l}\text { Mother } \\
\text { (with } \\
\text { Alzheimer's) }\end{array}$ & $\begin{array}{l}\text { Painting, } \\
\text { needlework }\end{array}$ & Home \\
\hline 5. & Joy & 77 & $\begin{array}{l}\text { Former (until } \\
4 \text { months } \\
\text { previously) }\end{array}$ & $\begin{array}{l}\text { Husband } \\
\text { (with } \\
\text { Alzheimer's) }\end{array}$ & $\begin{array}{l}\text { Painting, } \\
\text { ceramics, } \\
\text { needlework, } \\
\text { pastels, } \\
\text { crayons }\end{array}$ & Home \\
\hline 6. & Pamela & 76 & Current & $\begin{array}{l}\text { Husband } \\
\text { (with } \\
\text { vascular } \\
\text { dementia) }\end{array}$ & $\begin{array}{l}\text { Embroidery, } \\
\text { sewing, book } \\
\text { making }\end{array}$ & Home \\
\hline
\end{tabular}




\section{Table 2: Interview Topic Guide}

(All questions were asked flexibly and following up the participant's lead)

1. Could you tell me a little bit about yourself?

2. How would you describe your experience of being a carer? How has it affected your day-to-day life, health?

3. How did your interest in art come about? (Did you engage in art-making before becoming a carer or is this a more recent interest?)

4. Could you tell me about the forms of arts and crafts you currently engage in?

5. Does your work express certain themes? Have these changed over time?

6. What do you feel you gain from creative activity?

7. Can you tell me about the pieces you have shown me today? (Why are these of significance to you? Where did you draw inspiration from? What do you think they suggest about you as a person?)

8. Or if participants are without photos/ pieces of art work ask...Can you describe something that you have made recently and what the creative processes were?

9. How does engaging in arts and crafts influence your feelings about yourself?

10. Are there any ways in which you feel your art/craft making helps you to manage being a full- time carer? 
Table 3: Key themes and subthemes relating to carer-givers' experiences of care-giving for loved ones with dementia

\begin{tabular}{|l|l|}
\hline Theme & Subthemes \\
\hline $\begin{array}{l}\text { 'It's twenty-four seven': The intensity of the } \\
\text { care-giving experience }\end{array}$ & $\begin{array}{l}\text { A relentless battle } \\
\text { The burden of responsibility } \\
\text { Feeling engulfed and exhausted } \\
\text { Feeling concerned about the } \\
\text { impact of care-giving on own health }\end{array}$ \\
\hline 'What about me?': Erosion of identity & $\begin{array}{l}\text { Having to put on a brave face } \\
\text { Care-giving as an identity marker } \\
\text { Sacrificing personal interests } \\
\text { Feeling pushed to the limits of } \\
\text { endurance }\end{array}$ \\
\hline $\begin{array}{l}\text { helpless about the loved one's deterioration } \\
\text { and loss }\end{array}$ & $\begin{array}{l}\text { Grieving for the loved one } \\
\text { Feeling out of control } \\
\text { Losing touch with the outside world }\end{array}$ \\
\hline 'If we go anywhere we usually go together': & $\begin{array}{l}\text { Taking on a supervisory role } \\
\text { Experiencing role reversal } \\
\text { Impact of dementia on relationships } \\
\text { Difficulties relating to loved one and } \\
\text { wider family } \\
\text { Experiencing a stronger } \\
\text { relationship with the loved one }\end{array}$ \\
\hline life & $\begin{array}{l}\text { Making the most of life } \\
\text { Concerns about an uncertain future } \\
\text { Resignation and optimistic resolve }\end{array}$ \\
\hline
\end{tabular}


Table 4: Key themes and subthemes relating to carer-givers' experiences of art-making as a meaningful leisure occupation

\begin{tabular}{|l|l|}
\hline Theme & Subthemes \\
\hline $\begin{array}{l}\text { 'Like a drawing of breath': Art- } \\
\text { sense of respite from caring } \\
\text { and confinement }\end{array}$ & $\begin{array}{l}\text { Art-making... } \\
\text { Expresses confinement and offers a } \\
\text { means of escape } \\
\text { Offers absorption by the creative } \\
\text { process and sensuality of materials } \\
\text { Restores well-being and enables } \\
\text { recovery from care-giving } \\
\text { Encourages playful experimentation - } \\
\text { the antithesis of care-giving }\end{array}$ \\
$\begin{array}{l}\text { Processes the end of care-giving in rich } \\
\text { and personal ways }\end{array}$ \\
\hline $\begin{array}{l}\text { 'It's part of me': Self-expression } \\
\text { through art-making enhances } \\
\text { identity and resilience }\end{array}$ & $\begin{array}{l}\text { Art-making... } \\
\text { Offers opportunities for choice and } \\
\text { autonomy } \\
\text { Reclaims and transforms identity } \\
\text { Provides tangible evidence of coping } \\
\text { and resilience }\end{array}$ \\
\hline $\begin{array}{l}\text { 'Keeping that link going': Art- } \\
\text { making facilitates meaningful } \\
\text { outside of care-giving }\end{array}$ & $\begin{array}{l}\text { Art-making... } \\
\text { Establishes a focus beyond care-giving } \\
\text { Enables a closer relationship with the } \\
\text { care recipient through sharing/viewing } \\
\text { artwork together } \\
\text { Builds social connections based on } \\
\text { mutual interests rather than care-giving }\end{array}$ \\
\hline
\end{tabular}

